\title{
Article \\ Workforce Planning Framework for a Mobile Call Center Considering a Special Event
}

\author{
Thanyawan Chanpanit and Apinanthana Udomsakdigool *
}

check for updates

Citation: Chanpanit, T.;

Udomsakdigool, A. Workforce

Planning Framework for a Mobile

Call Center Considering a Special

Event. Energies 2022, 15, 1551

https://doi.org/10.3390/en15041551

Academic Editors: Annamária

R. Várkonyi-Kóczy and Amir Mosavi

Received: 8 January 2022

Accepted: 14 February 2022

Published: 19 February 2022

Publisher's Note: MDPI stays neutral with regard to jurisdictional claims in published maps and institutional affiliations.

Copyright: (C) 2022 by the authors. Licensee MDPI, Basel, Switzerland. This article is an open access article distributed under the terms and conditions of the Creative Commons Attribution (CC BY) license (https:// creativecommons.org/licenses/by/ $4.0 /)$.

\author{
Department of Production Engineering, Faculty of Engineering, King Mongkut's University of Technology \\ Thonburi (KMUTT), Bangkok 10140, Thailand; thanyawan.c@mail.kmutt.ac.th \\ * Correspondence: apinanthana.udo@kmutt.ac.th
}

\begin{abstract}
Workforce planning is essential in today's business management. If an organization can find and keep enough staff who have the right values, then they can provide high-quality service. This paper presents a workforce planning framework for selecting the best forecasting model in order to provide minimum wage and computer electricity costs for a mobile call center during the Songkran festival event, and to optimize workforce planning. The framework is constructed with four main steps: a study of a separate period; the separation of models with different data types; the simulation of models under different service levels to determine the number of customers waiting in a call center; and the evaluation of the models. The results from the proposed framework presented the best forecasting method and the optimal workforce plan. It is clear that this approach can assist in systematically selecting the best forecasting model. In addition, a workforce planner can use this framework to support workforce planning and cost evaluation in other event periods.
\end{abstract}

Keywords: workforce planning framework; forecasting; simulation; call center; Songkran festival event; energy saving; energy management

\section{Introduction \\ 1.1. Motivation}

Energy management is crucial to economic and environmental requirements. Many companies are turning to energy-saving programs to reduce their operating costs. In the call center industry, the purpose of business is to deliver customer service at the lowest possible cost. Therefore, reducing energy usage and increasing quality service level are paramount to helping achieve workforce planning management, especially in the case if special events in which the number of incoming calls drastically increases. Effective workforce planning when considering a special event is essential to a high-performing call center. In Thailand, the Songkran festival or Thai New Year is the most important holiday. It is celebrated in April, from the 13th to the 15th. The statistics presented by the Tourism Authority of Thailand (2017) reported that the total economic impact of spending during the Songkran festival 2017 was THB 45.428 billion, defining a 14.40 per cent increase over the same period last year [1].

During the Songkran festival period, Thai people spend more money on activities, such as eating, traveling, and shopping, than in other periods. One of the most common expenditures is on new mobile phones. To generate income for a mobile phone business, new mobile phone promotion during this festival is an important strategy. In addition, during this period, mobile phone usage associated with these activities is expected to increase two- to three-fold. This substantial growth in traffic across the network may lead to troublesome changes in network performance. Thus, during the Songkran festival period, the number of incoming calls in mobile call centers is higher than that in other periods. The preparation of an appropriate number of agents is significantly beneficial for call center services. Accurate incoming call and average handling time forecasting must be 
determined effectively in workforce planning to define the number of agents needed for customer satisfaction [2].

\subsection{Related Work}

Workforce planning is an essential construct in the development of human resource management (HRM), and is used as a strategic planning concept $[3,4]$. Thus, effective workforce planning is key for strategic planning $[5,6]$. This paper proposes a workforce planning framework for a mobile call center during a special event, the Songkran Festival. The objective of this framework was to find an accurate forecasting model and to optimize the number of agents in workforce planning with a simulation model. The resulting plan was executed considering the total cost of the event, including wages and the electricity cost of computers.

Data collection systems have become necessary for workforce planning in call centers [7]. The accuracy of the forecasting method used is one factor of call center management, and forecasting methods need to be compared to determine the best method [8,9]. Time series forecasting methods are used to forecast the number of incoming calls in a call center [10-12]. For staffing in modern call centers, a proposed staffing method using a simulation has been developed. The proposed method can enhance the accuracy and effectiveness of workforce management [13]. However, optimization modeling can be used to analyze cost effectiveness for workforce planning [14].

Many workforce planning frameworks have identified the development of workforce management. In this section, workforce planning framework concepts are compared in a methodological approach. The relevant framework is categorized by five aspects: (1) separation of the models by data collection (SMdc); (2) forecasting selection (FS); (3) forecasting classification by period (FCp); (4) formulation of simulation models by queuing theory (FSMQ); and (5) evaluation of model classification by cost (EMc), as shown in Table 1. The five aspects of the framework, and a summary of the relevant research gaps are as follows:

(1) Firstly, in general, there was a lack of model separation by data collection noted by the review papers $[13,15,16]$. In the review of papers $[13,15-28]$, there was also a lack of forecasting selection. A lack of forecasting classification by period was shown in the review papers $[13,16-20,22,23,25-29]$. In addition, it was noted in the review papers that there was no formulation of simulation models by queuing theory $[15,17-19,21-29]$. Furthermore, it was noted in review papers $[13,20-23,28,29]$ that there was no evaluation of model classification by cost. Therefore, this paper aims to address these gaps. Most frameworks are applied to separate models by the data collection aspect, in order to evaluate model classification by cost. However, our proposed framework includes all five aspects.

(2) Secondly, it was noted by review papers $[15,29]$ that future research is required to decide changes to tools and methodologies. The key outcomes and recommendations from the literature reviews included a methodological approach for workforce management. The proposed workforce planning framework in a call center is a new concept in the methodological approach.

(3) Finally, it was noted in the review paper [25] that a future research direction should implement decision-making approach models. This paper proposes the workforce planning framework for decision making during a special event.

Our proposed workforce planning framework is composed of two important parts: forecasting and workforce planning. In special events such as the Songkran Festival, it is important for workforce planning management to prepare an accurate number of agents to reduce customer service time and total cost. 
Table 1. Comparison of the related framework methodological approach with the proposed frameworks.

\begin{tabular}{|c|c|c|c|c|c|c|c|}
\hline \multirow{2}{*}{$\begin{array}{l}\text { Article } \\
\text { Number }\end{array}$} & \multirow{2}{*}{ Framework } & \multirow{2}{*}{ Purpose } & \multicolumn{5}{|c|}{ Methodological Approach } \\
\hline & & & SMdc & FS & $\mathrm{FCp}$ & FSMQ & EMc \\
\hline 1 & $\begin{array}{l}\text { Framework for workforce } \\
\text { management [13] }\end{array}$ & $\begin{array}{c}\text { Consecutive staffing solution } \\
\text { using simulation }\end{array}$ & & & & $\checkmark$ & \\
\hline 2 & $\begin{array}{c}\text { Enumerative constraint } \\
\text { framework [17] }\end{array}$ & $\begin{array}{l}\text { Airline engineering manpower } \\
\text { cost optimization }\end{array}$ & $\checkmark$ & & & & $\checkmark$ \\
\hline 3 & $\begin{array}{l}\text { Workforce planning framework } \\
\text { using structured equations [18] }\end{array}$ & Strategic workforce planning & $\checkmark$ & & & & $\checkmark$ \\
\hline 4 & $\begin{array}{l}\text { Strategic workforce planning } \\
\text { framework [29] }\end{array}$ & $\begin{array}{l}\text { Strategic workforce planning in } \\
\text { healthcare }\end{array}$ & $\boldsymbol{v}$ & $\checkmark$ & & & \\
\hline 5 & $\begin{array}{l}\text { Workforce planning and } \\
\text { deployment framework [15] }\end{array}$ & $\begin{array}{c}\text { Hospital reservation call center } \\
\text { with abandonment cost and } \\
\text { multiple tasks }\end{array}$ & & & $\checkmark$ & & $\checkmark$ \\
\hline 6 & $\begin{array}{c}\text { Framework of workforce } \\
\text { planning, operations, and risk } \\
\text { management [19] }\end{array}$ & Stochastic control problems & $\boldsymbol{V}$ & & & & $\checkmark$ \\
\hline 7 & $\begin{array}{l}\text { Framework for optimizing call } \\
\text { center staffing [20] }\end{array}$ & $\begin{array}{l}\text { Computing optimal staffing } \\
\text { levels in a call center when } \\
\text { traditional methods fail. }\end{array}$ & $\boldsymbol{V}$ & & & $\boldsymbol{V}$ & \\
\hline 8 & $\begin{array}{l}\text { Framework for capacity and } \\
\text { operations planning [21] }\end{array}$ & $\begin{array}{l}\text { Servicing organizations } \\
\text { employing workers with } \\
\text { intellectual disabilities }\end{array}$ & $\checkmark$ & & $\checkmark$ & & \\
\hline 9 & $\begin{array}{l}\text { Fuzzy input-output } \\
\text { optimization modeling } \\
\text { framework [22] }\end{array}$ & $\begin{array}{l}\text { Allocating human resources in } \\
\text { organizations operating under } \\
\text { crisis conditions }\end{array}$ & $\checkmark$ & & & & \\
\hline 10 & $\begin{array}{l}\text { Framework for new workforce } \\
\text { skills [23] }\end{array}$ & The era of industry 4.0 & $\checkmark$ & & & & \\
\hline 11 & Rescheduling framework [24] & $\begin{array}{l}\text { Intraday updating of call center } \\
\text { agent schedules }\end{array}$ & $\boldsymbol{v}$ & & $\checkmark$ & & $\checkmark$ \\
\hline 12 & $\begin{array}{l}\text { Activity-based cost } \\
\text { framework [16] }\end{array}$ & $\begin{array}{l}\text { Workforce scheduling in terms of } \\
\text { performance and cost. } \\
\text { Location selection of a }\end{array}$ & & & & $\checkmark$ & $\checkmark$ \\
\hline 13 & Decision-making framework [25] & $\begin{array}{l}\text { temporary hospital during the } \\
\text { COVID-19 pandemic }\end{array}$ & $\checkmark$ & & & & $\boldsymbol{v}$ \\
\hline 14 & $\begin{array}{l}\text { Multi-model assembly line } \\
\text { balancing framework [26] }\end{array}$ & $\begin{array}{l}\text { Balancing workload and } \\
\text { workforce capacity in } \\
\text { lean management }\end{array}$ & $\checkmark$ & & & & $\checkmark$ \\
\hline 15 & Optimal staffing framework [27] & $\begin{array}{l}\text { Randomly selecting a number } \\
\text { of servers }\end{array}$ & $\boldsymbol{r}$ & & & & $\checkmark$ \\
\hline 16 & $\begin{array}{c}\text { Job demands and resources } \\
\text { framework [28] }\end{array}$ & $\begin{array}{l}\text { Early childhood } \\
\text { teacher workforce }\end{array}$ & $\checkmark$ & & & & \\
\hline 17 & $\begin{array}{l}\text { Workforce planning framework } \\
\text { in a call center (our } \\
\text { proposed framework) }\end{array}$ & Special event planning & $\checkmark$ & $\checkmark$ & $\checkmark$ & $\boldsymbol{v}$ & $\checkmark$ \\
\hline
\end{tabular}

\subsection{Empirical Study on a Call Center}

An empirical study was performed on a mobile communication call center company in Thailand. There were four types of customer questions: (1) billing, (2) internet, (3) promotion, and (4) general information. The workforce planner forecasted incoming calls for all questions by time of day. Then, the number of agents was scheduled for the workforce biweekly. This call center operated $24 \mathrm{~h}$ a day. The working times were separated into three shifts; the first shift started at 8.00 a.m. and went on to 5.00 p.m.; the second shift was from 4.00 p.m. to 1.00 a.m.; and the third shift was from 12.00 a.m. to 9.00 a.m. The existing workforce planning method is shown in Figure 1. The incoming calls were forecasted by the multiplicative decomposition forecasting method. Erlang $\mathrm{C}$ under the $80 / 20$ service level was applied to define the number of agents. 


\begin{tabular}{|c|c|}
\hline 1. Forecasting incoming calls & 2. Determining the number of agents \\
\hline Forecast by the multiplicative & Erlang $C$ under $80 / 20$ service level \\
\hline decomposition forecasting method & \\
\hline
\end{tabular}

Figure 1. The existing workforce planning method.

During the Songkran Festival, the case study company offers promotions, such as the addition of internet packages for travel, cooperation packages with restaurants and hotels, new mobile phone packages, and a free mobile cover for water protection when a bill is paid at the store, to increase business income. The promotion packages and greater mobile phone usage for activities during the Songkran festival period affect the number of incoming calls. In this period, the number of incoming calls is higher than that in other periods.

Currently, the existing workforce planning method from empirical study consists of forecasting by the multiplicative decomposition forecasting method and generating the number of agents needed under the $80 / 20$ service level by the Erlang $C$ formula. The workforce planner forecasts incoming call data from all customer questions. Then, the call center uses these data to calculate the number of agents necessary. In addition to the data described, the number of customers waiting in a call center and average handling time during the Songkran festival are high. Therefore, the number of agents planned is not enough to service the incoming calls, reducing customer satisfaction. Thus, we propose a workforce planning framework that identifies planning process steps and evaluates models by cost during the Songkran festival event.

This framework enhances the workforce management at the call center step by step. In the first step, the incoming calls and average handling time are separated into three periods: before the event, during the event, and after the event. The second step includes data collection, time series forecasting, and the defining of the number of agents by the proposed and existing workforce planning models. For the third step, the customers waiting in the call center from the two models are simulated with actual data. The last step is the evaluation of energy cost. This conceptually contributes to the discussion of how the different workforce planning models affect energy cost during the Songkran festival.

This paper is organized as follows. The framework and methodology are presented in Section 2. Then, the evaluation of this study is presented and discussed in Section 3. In Section 4, the validation of the workforce planning framework is embedded by the conceptual framework in different scenarios. The conclusions are presented in Section 5.

\section{Workforce Planning Framework in the Call Center}

The framework proposed in this paper presents a simulation process of forecasting and workforce planning in a call center. The entire framework process consists of four sections: data analysis, model definition, model simulation, and model evaluation, as shown in Figure 2. The details are as follows. 


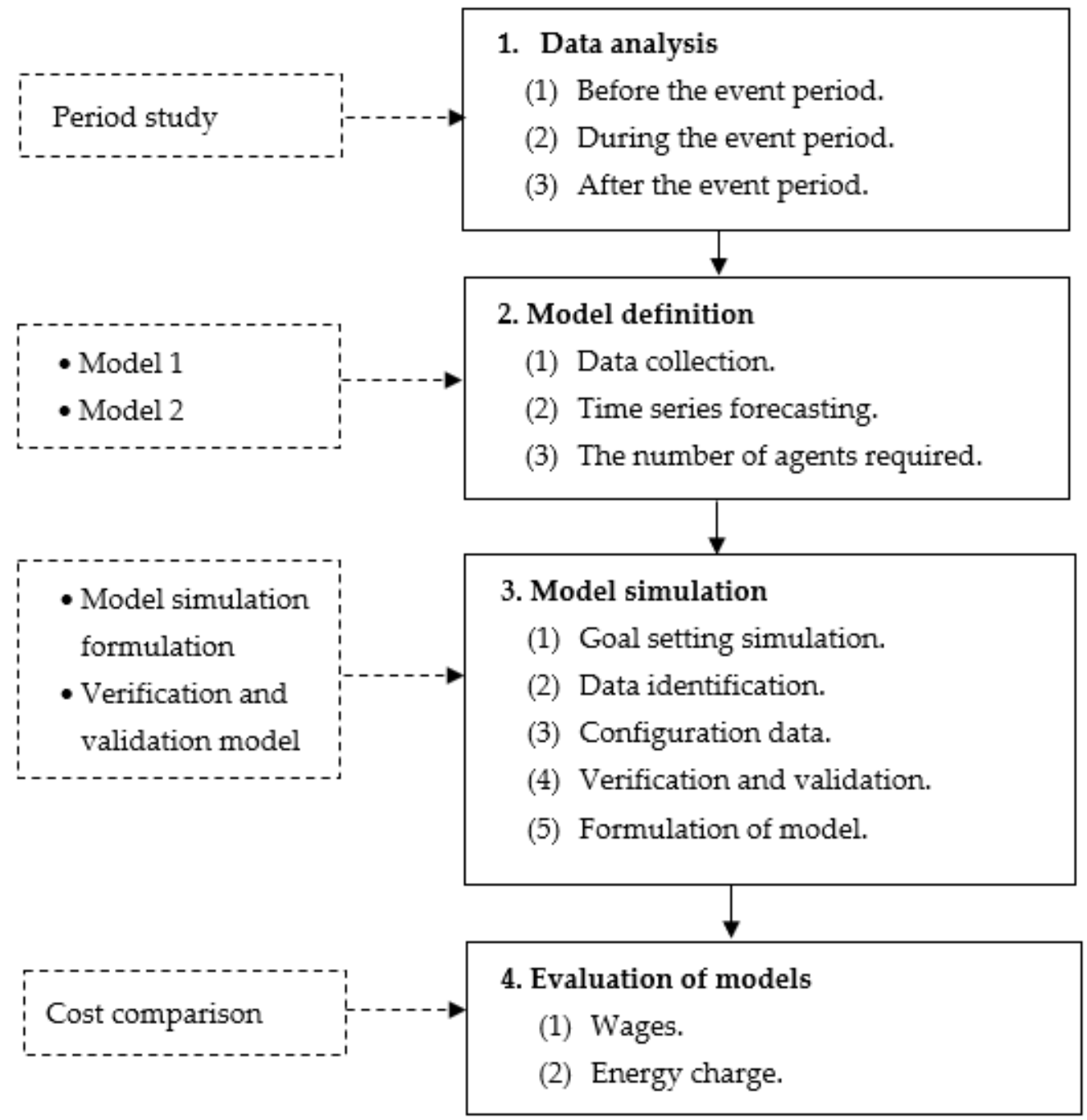

Figure 2. Workforce planning framework in a call center.

\subsection{Data Analysis}

As shown in Figure 2, the first step of this framework is the analysis of the incoming calls and average handling times during the Songkran festival period and non-festival period in 2016-2018. The studied periods included three periods: a week before the Songkran festival, during the Songkran festival, and a week after the Songkran festival. There were three separate periods studied, as shown in Equations (1)-(3). The timeline was disaggregated into three periods, as shown in Figure 3.

$$
B_{i}=\left\{B_{i_{1}}, B_{i_{2}}, B_{i_{3}}\right\}
$$

where $B_{i}$ represents a set of time series of calls in the week before the event period on the days corresponding to those of the event:

$B_{i_{1}} \quad$ represents the calls on the first day, a week before the event period;

$B_{i_{2}}$ represents the calls on the second day, a week before the event period;

$B_{i_{3}}$ represents the calls on the last day, a week before the event period.

$$
S_{i}=\left\{S_{i_{1}}, S_{i_{2}}, S_{i_{3}}\right\}
$$

where $S_{i}$ represents a set of time series of calls during the event period:

$S_{i_{1}} \quad$ represents the calls on the first day during the event period;

$S_{i_{2}}$ represents the calls on the second day during the event period; 
$S_{i_{3}}$ represents the calls on the last day during the event period.

$$
A_{i}=\left\{A_{i_{1}}, A_{i_{2}}, A_{i_{3}}\right\}
$$

where $A_{i}$ represents a set of time series of calls in the week after the event period on the days corresponding to those of the event:

$A_{i_{1}}$ represents the calls on the first day, a week after the event period;

$A_{i_{2}}$ represents the calls on the second day, a week after the event period;

$A_{i_{3}}$ represents the calls of the last day, a week after the event period.

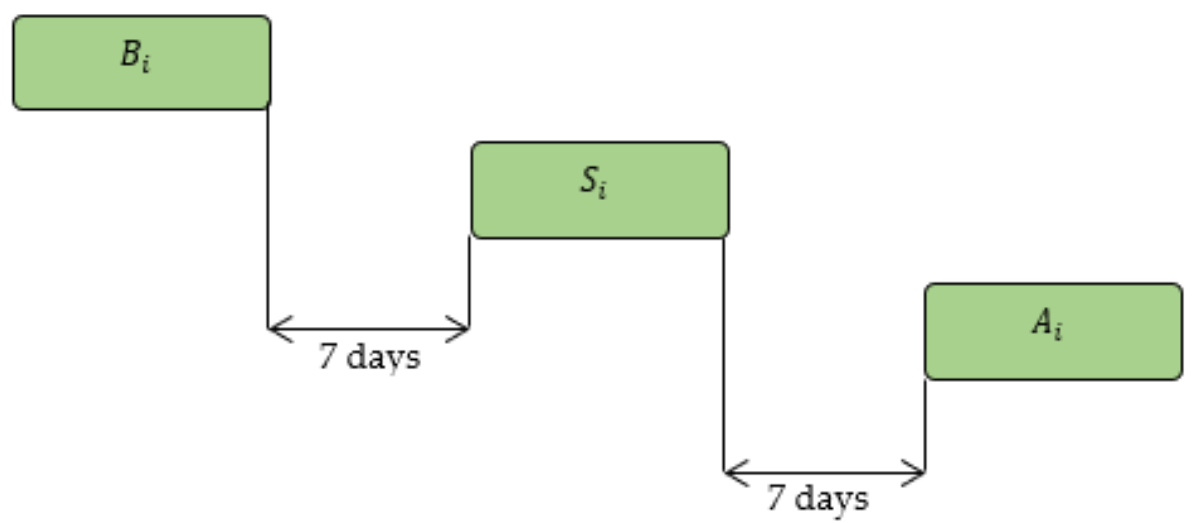

Figure 3. Timeline for the three periods.

\subsection{Model Definition}

This section presents two models from three steps: data collection, time series forecasting, and the number of agents required. The results of this section provide the number of calls for a two-service level approach. The two models of workforce planning are as follows: Model 1 is the optimal workforce planning model; Model 2 is the existing workforce planning model. A detailed description of each model is presented in Table 2.

Table 2. The details of the two models.

\begin{tabular}{ccc}
\hline Step Detail & Model 1 & Model 2 \\
\hline Step 1 Data collection & & \\
1.1 Separation of data types of customer questions & & \\
1.2 All data types of customer questions & & \\
Step 2 Time series forecasting & & \\
2.1 The proposed forecasting method & \\
2.2 Existing forecasting method & & \\
Step 3 The number of agents required & & \\
3.1 Classification service level & & \\
3.2 Existing service level & & \\
\hline
\end{tabular}

\subsubsection{Data Collection}

The incoming call volumes from all customer questions were prepared in two ways, as follows.

\section{Separation of Data Types of Customer Questions}

The data types of customer questions were used to select the forecasting model(s). The time interval for forecasting incoming calls and the average handling time was one hour.

\section{All Data Types of Customer Questions}

All data types of customer questions were used to forecast incoming calls and the average handling time. The time interval for forecasting was one hour. 


\subsubsection{Time Series Forecasting}

The proposed and existing forecasting methods for forecasting the number of incoming calls and average handling time are as follows.

The Proposed Forecasting Method

In this step, the proposed incoming call forecasting is defined. Three forecasting methods-Holt's two parameter, Holt-Winters, and the seasonal autoregressive integrated moving average (SARIMA) - were applied and compared in terms of mean absolute percentage error (MAPE). The formulations of all forecasting methods are as follows.

\section{(1) Holt's two parameter}

Holt's two parameter equation is shown in Equation (4). Two smoothing parameters (level component $(\alpha)$ and trend component $(\beta)$ ) are optimized by minimizing the forecasting error, as shown in Equation (7). Equations (5) and (6) provide the level of the series at time $t$ and the slope of the data series at time $t$, respectively [30].

$$
F=L_{t}+b_{t} m
$$

where:

$$
\begin{aligned}
& L_{t}=\alpha Y_{t}+(1-\alpha)\left(L_{t-1}+b_{t-1}\right) \\
& b_{t}=B\left(L_{t}-L_{t-1}\right)+(1-\beta) b_{t-1}
\end{aligned}
$$

minimize:

$$
E=\frac{100 \%}{n} \sum_{t=1}^{n}\left|\frac{A_{t}-F_{t+\frac{n}{t}}}{A_{t}}\right|
$$

where

$F=$ the forecasted value for $\mathrm{m}$ periods;

$\alpha=$ the level component;

$\beta=$ the trend component;

$L_{t}=$ the level of the series at time $\mathrm{t}$;

$b_{t}=$ the slope of the data series at time $\mathrm{t}$.

\section{(2) Holt-Winters method}

The multiplicative Holt-Winters method is applied to forecast the call volume, as shown in Equation (8). It is calculated from three components: the level component $\left(L_{t}\right)$ in Equation (9); the trend component $\left(T_{t}\right)$ in Equation (10); and the seasonal component $\left(S_{t}\right)$ in Equation (11). Three smoothing parameters $(\alpha, \beta$, and $\gamma)$ are optimized by minimizing the forecasting error (Min E) by Equation (12) [30].

$$
F_{t+\frac{n}{t}}=\left(L_{t}+T_{t} n\right) S_{t-s+n}
$$

where:

$$
\begin{gathered}
L_{t}=\alpha \frac{Y_{t}}{S_{t-s}}+(1-\alpha)\left(L_{t-1}+T_{t-1}\right) \\
T_{t}=\beta\left(L_{t}-L_{t-1}\right)+(1-\beta) T_{t-1} \\
S_{t}=\gamma \frac{Y_{t}}{L_{t}}+(1-\gamma) S_{t-s}
\end{gathered}
$$

minimize:

$$
E=\frac{100 \%}{n} \sum_{t=1}^{n}\left|\frac{A_{t}-F_{t+\frac{n}{t}}}{A_{t}}\right| ; 0<\alpha, \beta, \gamma<1
$$

where:

$L_{t}=$ the level component;

$S_{t}=$ the seasonal component; 
$T_{t}=$ the trend component;

$F_{n}=$ the forecast $\mathrm{n}$ periods ahead;

$Y=$ the observation;

$s=$ the seasonal period;

$t=$ time;

$n=$ the number of time periods (i.e., $1,2, \ldots, n$ periods);

$\alpha=$ a level-related parameter;

$\beta=$ a slope-related parameter;

$\gamma=$ a smoothing constant related to the seasonal factor.

\section{(3) SARIMA model}

This forecasting method is calculated by including seasonal terms. There are two separate parts: the nonseasonal part of the model is defined by the values of (p, d, q), and the seasonal part of the model is defined by the values of $(\mathrm{P}, \mathrm{D}, \mathrm{Q}) \mathrm{m}$ [31-34]. The SARIMA model is obtained by adding an additional seasonal term to the ARIMA models. SARIMA combines the advantages of the autoregressive model and the moving average model. The SARIMA forecasting method is represented by Equation (13):

$$
\mathrm{Y}_{\mathrm{t}}=\operatorname{SARIMA}(\mathrm{p}, \mathrm{d}, \mathrm{q}) \times(\mathrm{P}, \mathrm{D}, \mathrm{Q})
$$

where:

$Y_{t}=$ the forecast value at time $t$;

$\mathrm{p}=$ the number of autoregressive items;

$\mathrm{d}=$ the number of nonseasonal differences needed for the data to be stationary;

$\mathrm{q}=$ the number of lagging forecast errors in the forecast equation;

$\mathrm{P}=$ the number of seasonal autoregressive terms;

$\mathrm{D}=$ the number of seasonal differences;

$\mathrm{Q}=$ the number of the seasonal moving average;

$\mathrm{M}=$ the number of periods (the hours were divided into 24 periods, $\mathrm{m}=24$ ).

For the autoregressive model, a linear combination of the past values of the variable is used to forecast the future of the variable, as shown in Equation (14):

$$
A R_{t}=\theta_{0}+\theta_{1} A R_{t-1}+\theta_{2} A R_{t-2}+\cdots+\theta_{p} A R_{t-p}+\varepsilon_{t}
$$

where:

$A R=$ the observation at time $t$;

$p=$ the previous observations;

$\theta_{n}=$ the parameters $(n=1,2,3, \ldots, p)$;

$\varepsilon_{t}=$ the white noise.

For the moving average model $M A(q)$, the forecast value is calculated by Equation (15). The past forecast errors are included in the equation.

$$
M A_{t}=\phi_{0}+\varepsilon_{t}+\phi_{1} \varepsilon_{t-1}+\phi_{2} \varepsilon_{t-2}+\cdots+\phi_{q} \varepsilon_{t-q}
$$

where

$M A=$ the observation at time $t$

$\phi_{n}=$ the parameters $(n=1,2,3, \ldots, q)$;

$\varepsilon_{t-k}=$ the error at time $t(k=1,2,3 \ldots, q)$.

Then, the autoregressive integrated moving average (ARIMA) model combines autoregression and a moving average represented by Equation (16). $\hat{f}_{t}$ denotes the differenced series.

$$
\hat{f}_{t}=\theta_{0}+\theta_{1} \hat{f}_{t-1}+\theta_{2} \hat{f}_{t-2}+\cdots+\theta_{p} \hat{f}_{t-p}+\phi_{1} \varepsilon_{t-1}+\phi_{2} \varepsilon_{t-2}+\cdots+\phi_{q} \varepsilon_{t-q}+\varepsilon_{t}
$$




\section{Existing Forecasting Method}

The existing forecasting method of the case study is multiplicative decomposition, as shown in Equation (17). In Equation (16), there are three components: a trend-cycle component $\left(T_{t}\right)$, a seasonal component $\left(S_{t}\right)$, and an irregular component $\left(E_{t}\right)$. The trendcycle component is calculated as a moving average that is centered at $t$. The estimated trend also depends on the seasonality of the time series. In this paper, the moving average is determined in hours, and the data on the Songkran festival event calls are obtained from 3 days per year. We suppose that the time series of the Songkran festival event calls start on the 1st day in the first hour $(t=1)$, and we average the number of calls received per hour up through the 24th hour $(t=24)$. This average corresponds to a time of $t=12.5$ (the halfway point between the 1st hour and the 24th hour). Then, the equation of the trend at time $\mathrm{t}$ can be estimated as the centered average. It is formulated as $\hat{T}=\frac{1}{m} \sum_{j=-k}^{k} y_{t+j}$, where $\mathrm{m}=2 \mathrm{k}+1$ and $\mathrm{k}$ is the time in period $\mathrm{t}$. However, a detrended series can be calculated by determining $\frac{y_{t}}{\widehat{T}_{t}}$. Then, the average of the detrended values by period is the estimated seasonal component for each period. The values obtained are denoted by $\hat{S}_{t}$. Next, the irregular component at period $t$ is calculated by dividing by the estimated seasonal and trend-cycle components as $\hat{E}_{t}=\frac{y_{t}}{\left(\hat{T} \hat{S}_{t}\right)}[31]$.

$$
y_{t}=T_{t} \times S_{t} \times E_{t}
$$

where:

$T_{t}=$ the trend-cycle component in period $\mathrm{t}$;

$S_{t}=$ the seasonal component in period $\mathrm{t}$;

$E_{t}=$ the irregular component in period $\mathrm{t}$;

$t=$ time period.

\subsubsection{The Number of Agents Required}

We apply the Erlang $C$ formulation to determine the number of agents required in this paper, as shown in Equation (18), and its components are detailed in Equations (19)-(21). The formulation can be represented by $W\left(m, u, T_{A}, T_{R}\right)$, as shown in Equation (22) [35].

$$
E_{c}(m, u)=P(\text { call waiting })=\frac{\frac{u^{m}}{m !}}{\frac{u^{m}}{m !}+(1-\rho) \sum_{k=0}^{m-1} \frac{u^{k}}{k !}}
$$

where:

$$
\begin{aligned}
\mathrm{u} & =\frac{\lambda}{\mu} \\
\rho & =\frac{u}{m} \\
\mu & =\frac{1}{T_{A}}
\end{aligned}
$$

Then,

$$
\mathrm{W}\left(\mathrm{m}, \mathrm{u}, T_{A}, T_{R}\right)=P\left(\text { waiting time } \leq T_{R}\right)=1-E_{\mathcal{c}}(m, u) e^{-(m-u) \frac{1}{T_{A}}}
$$

where:

$\lambda=$ call arrival rate;

$T_{A}=$ average handling time;

$m=$ number of agents;

$T_{R}=$ target waiting time. 


\section{Classification Service Level}

In this step, service level is classified into three categories: (1) service level under $90 / 10$, in which at least $90 \%$ of the customers must wait no more than $10 \mathrm{~s}$; (2) service level under $80 / 20$, in which at least $80 \%$ of the customers must wait no more than 20 s; and (3) service level under $70 / 30$, in which at least $70 \%$ of the customers must wait no more than $30 \mathrm{~s}$. The details are shown in Table 3.

Table 3. Three categories of service level.

\begin{tabular}{clc}
\hline & Categories & Incoming Calls Volume \\
\hline 1. & Service level under 90/10 rule & $\geq 80 \%$ \\
2. & Service level under 80/20 rule & $10-15 \%$ \\
3. & Service level under 70/30 rule & $\leq 5 \%$ \\
\hline
\end{tabular}

Existing Service Level

In this step, we fix the queuing model under the $80 / 20$ rule, in which at least $80 \%$ of the customers must wait no more than $20 \mathrm{~s}$.

\subsection{Model Simulation}

This section explores how the number of customers waiting in the call center are applied by simulation models. The simulation methodology process of this research is shown in Figure 4. A detailed description of each process step is presented as follows:

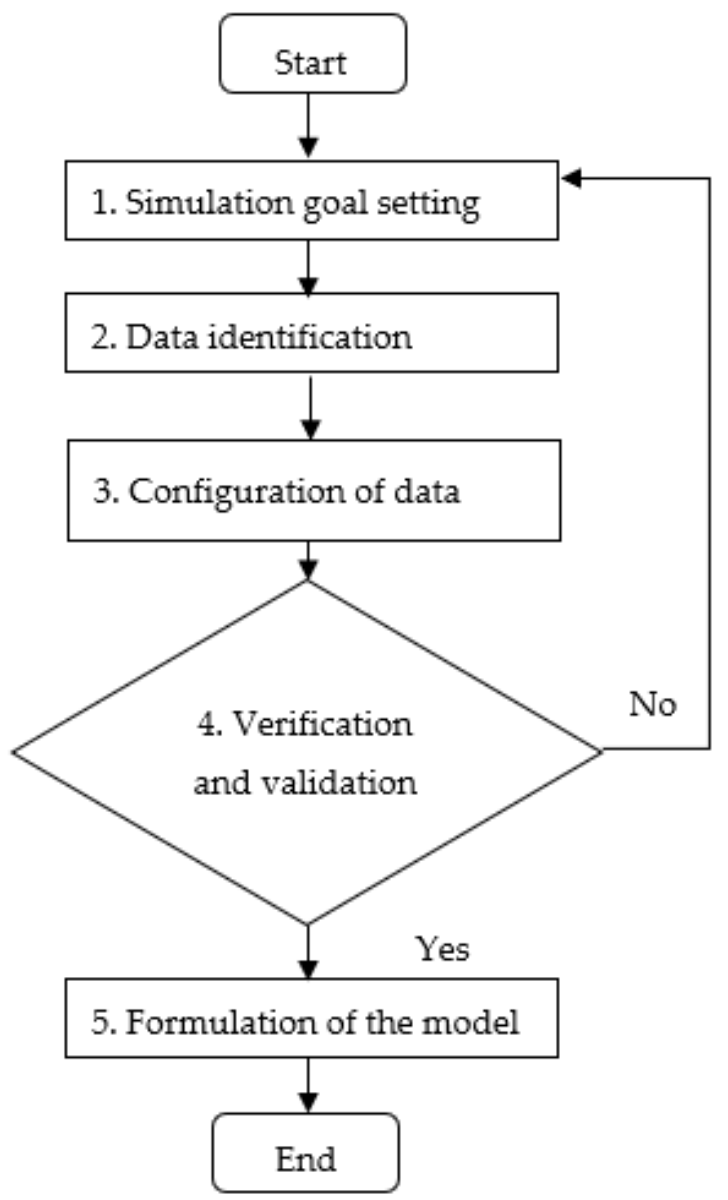

Figure 4. Simulation methodology process. 


\subsubsection{Goal Setting Simulation}

This step sets the goal for finding the number of agents in the call center and the number of queues. The simulation study goals are necessary because we can compare the existing model and the optimal model from the datasets of incoming calls and average handling time [36].

\subsubsection{Data Identification}

Data identification is an essential task for simulation. Then, the challenge in simulation is connected to data quality and data availability [37]. We collected data for the simulation of two models (Model 1 and Model 2) and the actual data for incoming calls in three periods in 2019. The actual data were divided by hour from $24 \mathrm{~h}$ per day.

\subsubsection{Configuration of the Data}

The incoming calls and average handling time were used to formulate the simulation model. For data analysis, the number of agents and the waiting time of each shift were fitted to the appropriate queueing theory using the input analyzer of the software Flexsim. The scenario modeling was analyzed by 3D image processing in this software [38]. The process of configuring data for simulation is shown in Figure 5. There are three parts, which are detailed as follows.

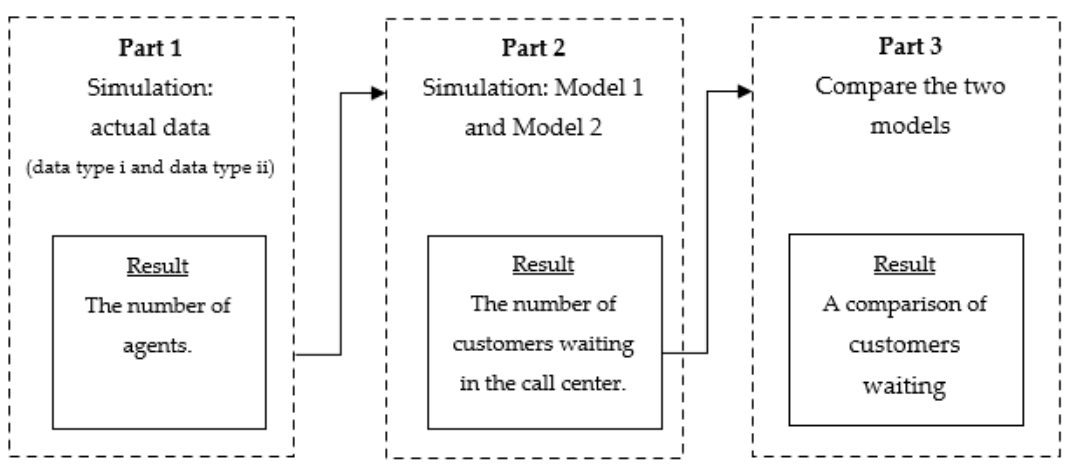

Figure 5. Process of configuring data for simulation.

Part 1 First, two data types - data type 1 and data type 2 - of the actual data are simulated. Data type 1 is incoming calls from three categories at the service level, and data type 2 is incoming calls with an $80 / 20$ service level. Then, the result is the number of agents required for each type.

Part 2 The actual number of agents from part 1 is used for simulation with Model 1 (following data type 1) and Model 2 (following data type 2) to determine the number of customers waiting in a call center.

Part 3 Finally, the numbers of customers waiting from Model 1 and Model 2 are compared.

\subsubsection{Verification and Validation}

Model verification and validation are conducted to test the accuracy of the statistics, regardless of whether the model is appropriate for simulation. We used a significance level of 0.05 (significant < 0.05) for the percentage error for simulation. The percentage error of the simulation is formulated as Equation (23):

$$
P E=\left|\frac{S-A}{A}\right| \times 100 \%
$$

where:

$P E=$ percentage error;

$S$ = simulation data;

$A=$ actual data. 
Then, the average of the results of the models and the percentage difference ratios are calculated by Equations (24) and (25):

$$
\begin{gathered}
\bar{S}=\frac{1}{2}\left(S_{1}+S_{2}\right) \\
P D=\frac{\left|S_{1}+S_{2}\right|}{\bar{S}} \times 100 \%
\end{gathered}
$$

where:

$P D=$ percentage difference;

$S_{1}=$ data results for Model 1;

$S_{2}=$ data results for Model 2 .

\subsubsection{Formulation of the Model}

In the last step, the simulation is formulated to present the optimal method of Model (1) and Model (2) by the number of customers waiting via Flexsim 2016 software. The number of customers waiting in a call center per hour is shown.

\subsection{Evaluating the Models}

In this step, Model (1) and Model (2) were evaluated by cost, wages and energy cost. The model that had the lowest total cost was the optimal solution.

\subsubsection{Wages}

This comparison step analyzes the wages according to the daily minimum wage rate in Bangkok of THB 331 [39]. The cost of three periods from the two models are compared. The total wages are calculated with Equation (26):

$$
W C=\sum_{i=1}^{s n} N_{i} \times W D \times C .
$$

where:

$W C$ = wages;

$W D=$ day number;

$C=$ daily minimum wage rate (which in Bangkok is THB 331);

$N=$ number of agents;

$i=$ shift number $(i=1,2, \ldots, s n)$.

\subsubsection{Energy Cost}

The energy cost is the electricity consumption cost calculated considering desktop computer model 2.3 GHz processor 3 GB RAM. This computer model uses an energy of 1200 watts [40]. The agents work for $8 \mathrm{~h}$ per shift, and one day has three shifts. The energy cost is calculated based on metropolitan electricity authority rates. The case study is classified into category 3, a medium-sized businesses with a voltage lower than 12 kilovolts [41]. The period of electricity consumption is divided into two periods: off-peak and on-peak periods. The off-peak periods are: (1) between 10:00 p.m. to 9:00 a.m. on Monday until Friday; and (2) between 12:00 a.m. to 12:00 p.m. on Saturday, Sunday, National Labor Day, and regular public holidays (excluding the royal plowing ceremony day and substitution holidays). The energy charge rate is THB 2.6627 per $\mathrm{kW}$-hour. The on peak period includes Monday to Friday from 09:00 a.m. to 10:00 p.m. The energy charge rate is THB 4.3555 per $\mathrm{kW}$-hour. The total energy cost is calculated by Equation (27), and the energy costs on peak and off peak are shown in Equations (28) and (29), respectively. The details of the energy costs in each shift are presented in Table 4.

$$
\text { Minimize } E C=E C_{o n}+E C_{o f f}
$$


where:

$$
\begin{aligned}
& E C_{o n}=\frac{N \times 1200 \times T}{1000} \times 4.3555 \\
& E C_{o f f}=\frac{N \times 1200 \times T}{1000} \times 2.6627
\end{aligned}
$$

where:

$E C$ = energy cost from desktop computer;

$E C_{o n}=$ energy cost from desktop computer during on peak;

$E C_{o f f}=$ energy cost from desktop computer during off peak;

$N=$ the number of agents;

$T=$ working hours for desktop computer.

Table 4. The energy costs for each shift.

\begin{tabular}{cccc}
\hline \multirow{2}{*}{ Shift No. } & \multirow{2}{*}{ Time Period } & \multicolumn{2}{c}{ Energy Cost (THB Per kW-Hour) } \\
& & Monday-Friday & Saturday and Sunday \\
\hline 1 & 08.00 a.m.-05.00 p.m. & 4.3555 & \\
2 & 04.00 p.m.-01.00 a.m. & 4.3555 (for 6 h) & 2.6627 \\
3 & 12.00 a.m.-09.00 a.m. & 2.6627 (for $3 \mathrm{~h})$ & \\
\hline
\end{tabular}

\section{Empirical Evaluation}

In this part, the results of the evaluation of the workforce planning framework in a call center are presented.

\subsection{Data Analysis Results}

Three periods, including during event and nonevent periods (before and after) were analyzed in terms of incoming calls and average handling time. The corresponding days a week before the Songkran festival period $\left\{B_{i_{1}}, B_{i_{2}}, B_{i_{3}}\right\}$ were April 6th, 7 th, and 8 th. The days during the Songkran festival period $\left\{S_{i_{1}}, S_{i_{2}}, S_{i_{3}}\right\}$ were April 13th, 14th, and 15th. The corresponding days a week after the Songkran festival period, $\left\{A_{i_{1}}, A_{i_{2}}, A_{i_{3}}\right\}$ were April 20th, 21st, and 22nd. The weekdays during 2016-2018 for each period are presented in Table 5.

Table 5. The weekday for each period in April.

\begin{tabular}{cccccc}
\hline Period & Day & April & Year 2016 & Year 2017 & Year 2018 \\
\hline$B_{i}$ & $B_{i_{1}}$ & 6 th & Wednesday & Thursday & Friday \\
& $B_{i_{2}}$ & 7 th & Thursday & Friday & Saturday \\
& $B_{i_{3}}$ & 8 th & Friday & Saturday & Sunday \\
$S_{i}$ & $S_{i_{1}}$ & 13 th & Wednesday & Thursday & Friday \\
& $S_{i_{2}}$ & 14 th & Thursday & Friday & Saturday \\
& $S_{i_{3}}$ & 15 th & Friday & Saturday & Sunday \\
$A_{i}$ & $A_{i_{1}}$ & 20 th & Wednesday & Thursday & Friday \\
& $A_{i_{2}}$ & 21 st & Thursday & Friday & Saturday \\
& $A_{i_{3}}$ & 22 nd & Friday & Saturday & Sunday \\
\hline
\end{tabular}

\subsection{Model Definition Results}

From Table 2, the details of the two models included three steps. In the first step, data collection was performed, and customer questions were classified in two ways: (1) four separate types of customer questions (billing, internet, promotions, and general information); and (2) all types of customer questions combined.

In the next step, the forecasting methods were applied to forecast the incoming calls for the two types of data classification, and the forecasting errors of all forecasting methods were evaluated. For data type 1, the Holt's two parameter method, the Holt-Winters method, and the SARIMA method were used to forecast both incoming calls and the 
average handling time for three periods. The method that provided a lower MAPE was selected. The MAPE of each forecasting method in each period is shown in Table 6. The parameter values in the parentheses are the values that provided the minimum forecasting error. For data type 2, multiplicative decomposition was applied. The MAPE of each period is shown in Table 7 . Figure 6 presents the incoming calls based on data type 1, data type 2 and the actual data. For each period, the number of calls was assessed in terms of trends and seasonality. The number of calls in the 10th hour on the second day during the Songkran festival of data type 2 was high, at 2158 calls. However, the number of calls in the 4 th hour on the second day of the period after the Songkran festival in the actual data was low, at 145 calls. Figure 7 compares the average handling times for data type 1, data type 2 and the actual data. The average handling time in the 16th hour on the second day during the Songkran festival of data type 2 was high, at $590 \mathrm{~s}$. The average handling time was low during the 1st hour during the first day of the period before the Songkran festival in the actual data, at $325 \mathrm{~s}$.

Table 6. Comparison of the MAPEs for data type 1.

\begin{tabular}{|c|c|c|c|c|c|}
\hline Forecasting Type & Data Type & Period & $\begin{array}{l}\text { Holt's Two Parameter } \\
\qquad(\alpha, \beta)\end{array}$ & $\begin{array}{l}\text { Holt-Winters } \\
\quad(\alpha, \beta, \gamma)\end{array}$ & $\begin{array}{c}\text { SARIMA } \\
(\mathrm{p}, \mathrm{d}, \mathrm{q}) \times(\mathrm{P}, \mathrm{D}, \mathrm{Q}) \mathrm{m}\end{array}$ \\
\hline \multirow{12}{*}{ 1. Incoming calls } & \multirow{3}{*}{ 1.1. Billing } & $B_{i}$ & $16.83(0.5,0.1)$ & $9.21(0.5,0.3,0.1)$ & $9.32(1,0,1)(0,1,1)[24]$ \\
\hline & & $S_{i}$ & $18.15(0.5,0.9)$ & $7.41(0.1,0.5,0.5)$ & $8.71(1,0,2)(1,1,1)[24]$ \\
\hline & & $A_{i}$ & $17.72(0.3,0.5)$ & $9.73(0.1,0.5,0.1)$ & $8.66(1,0,1)(0,1,1)[24]$ \\
\hline & \multirow{3}{*}{ 1.2. Internet } & $B_{i}$ & $19.81(0.7,0.5)$ & $11.45(0.1,0.9,0.1)$ & $10.26(1,0,1)(1,1,1)[24]$ \\
\hline & & $S_{i}$ & $17.26(0.5,0.9)$ & $13.58(0.1,0.3,0.2)$ & $12.42(1,0,2)(1,1,1)[24]$ \\
\hline & & $A_{i}$ & $21.19(0.2,0.8)$ & $10.25(0.2,0.5,0.5)$ & $11.63(1,0,1)(0,1,1)[24]$ \\
\hline & \multirow{3}{*}{ 1.3. Promotion } & $B_{i}$ & $16.73(0.5,0.1)$ & $9.73(0.4,0.3,0.1)$ & $10.82(1,0,1)(0,1,1)[24]$ \\
\hline & & $S_{i}$ & $14.61(0.1,0.5)$ & $8.52(0.1,0.2,0.1)$ & $11.30(1,0,1)(0,1,1)[24]$ \\
\hline & & $A_{i}$ & $23.11(0.1,0.9)$ & $8.21(0.1,0.5,0.1)$ & $14.74(1,0,1)(1,1,1)[24]$ \\
\hline & \multirow{3}{*}{$\begin{array}{l}\text { 1.4. General } \\
\text { information }\end{array}$} & $B_{i}$ & $14.23(0.8,0.1)$ & $11.22(0.1,0.4,0.5)$ & $10.52(1,0,1)(0,1,1)[24]$ \\
\hline & & $S_{i}$ & $15.43(0.5,0.9)$ & $9.12(0.5,0.1,0.1)$ & $9.32(1,0,2)(1,1,1)[24]$ \\
\hline & & $A_{i}$ & $20.22(0.3,0.8)$ & $12.29(0.8,0.5,0.1)$ & $10.34(1,0,1)(1,1,1)[24]$ \\
\hline \multirow{12}{*}{$\begin{array}{l}\text { 2. Average } \\
\text { handling time }\end{array}$} & \multirow[t]{3}{*}{ 2.1. Billing } & $B_{i}$ & $10.63(0.1,0.1)$ & $8.17(0.1,0.5,0.1)$ & $8.32(1,0,2)(0,1,1)[24]$ \\
\hline & & $S_{i}$ & $9.18(0.2,0.9)$ & $7.38(0.1,0.9,0.1)$ & $8.71(1,0,2)(1,1,1)[24]$ \\
\hline & & $A_{i}$ & $12.85(0.5,0.5)$ & $8.73(0.5,0.5,0.1)$ & $7.47(1,0,1)(0,1,1)[24]$ \\
\hline & \multirow[t]{2}{*}{ 2.2. Internet } & $B_{i}$ & $9.41(0.1,0.3)$ & $8.52(0.1,0.5,0.1)$ & $9.26(1,0,1)(1,1,1)[24]$ \\
\hline & & $S_{i}$ & $10.25(0.5,0.1)$ & $9.11(0.1,0.3,0.5)$ & $9.48(1,0,1)(0,1,1)[24]$ \\
\hline & \multirow{4}{*}{ 2.3. Promotion } & $A_{i}$ & $11.12(0.3,0.9)$ & $8.29(0.1,0.3,0.5)$ & $10.63(1,0,1)(0,1,1)[24]$ \\
\hline & & $B_{i}$ & $10.13(0.5,0.4)$ & $9.24(0.5,0.9,0.1)$ & $9.12(1,0,1)(0,1,1)[24]$ \\
\hline & & $S_{i}$ & $9.29(0.7,0.3)$ & $8.36(0.1,0.5,0.1)$ & $8.39(1,0,1)(1,1,1)[24]$ \\
\hline & & $A_{i}$ & $9.12(0.1,0.9)$ & $7.71(0.2,0.5,0.1)$ & $8.27(1,0,2)(1,1,1)[24]$ \\
\hline & \multirow{3}{*}{$\begin{array}{l}\text { 2.4. General } \\
\text { information }\end{array}$} & $B_{i}$ & $10.13(0.1,0.1)$ & $9.28(0.1,0.1,0.5)$ & $8.18(1,0,2)(0,1,1)[24]$ \\
\hline & & $S_{i}$ & $9.56(0.1,0.9)$ & $7.34(0.5,0.2,0.9)$ & $9.37(1,0,1)(1,1,1)[24]$ \\
\hline & & $A_{i}$ & $9.35(0.3,0.5)$ & $7.13(0.5,0.1,0.1)$ & $8.35(1,0,1)(1,1,1)[24]$ \\
\hline
\end{tabular}

Remark: bold values indicate the lowest forecasting error.

Table 7. The MAPEs for data type 2.

\begin{tabular}{ccc}
\hline Forecasting Type & Period & Multiplicative Decomposition \\
\hline \multirow{2}{*}{ 1. Incoming calls } & $B_{i}$ & 26.33 \\
& $S_{i}$ & 30.31 \\
2. Average handling time & $A_{i}$ & 32.11 \\
& $B_{i}$ & 19.87 \\
& $S_{i}$ & 18.21 \\
& $A_{i}$ & 18.32 \\
\hline
\end{tabular}




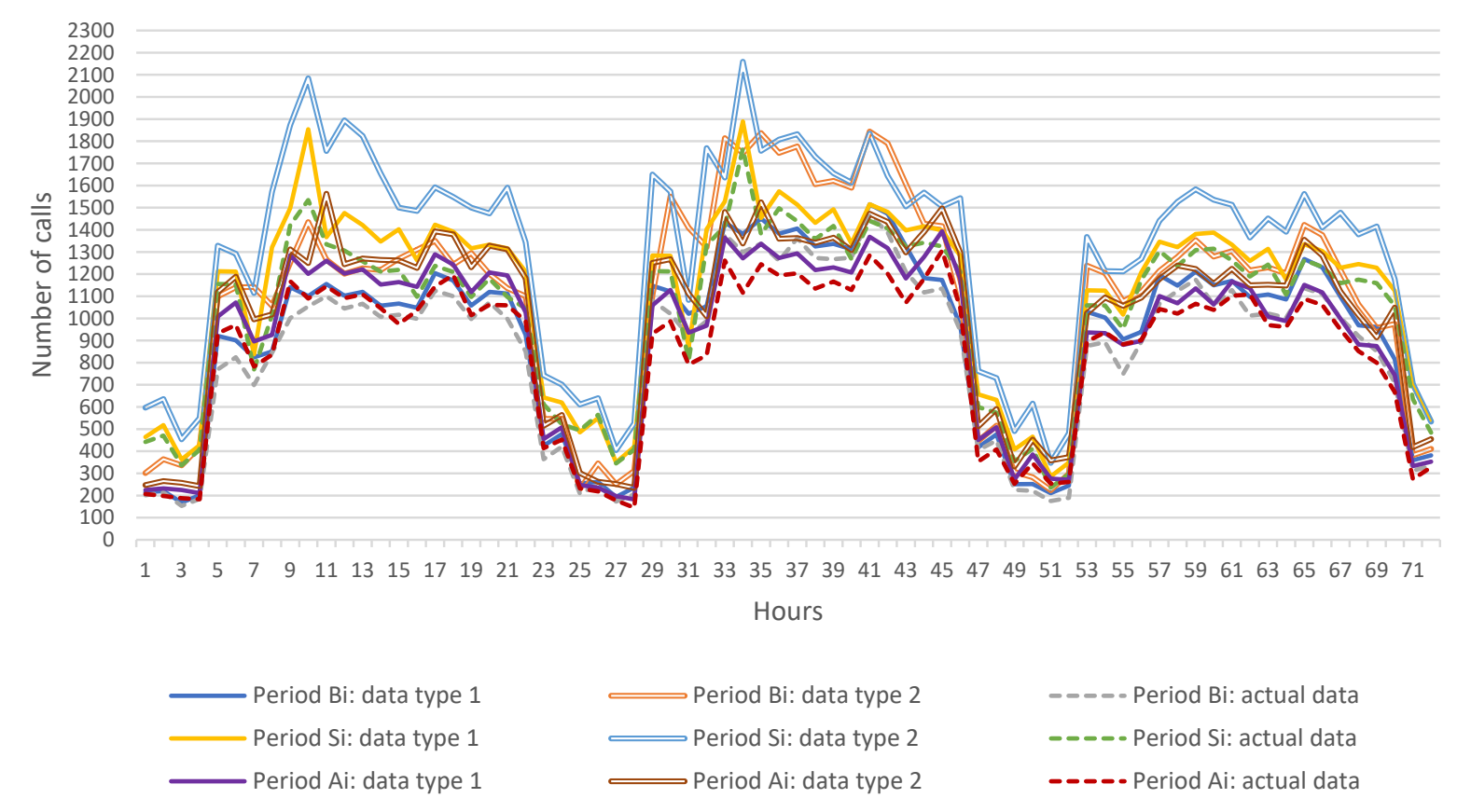

Figure 6. The incoming calls based on the two data types and actual data.

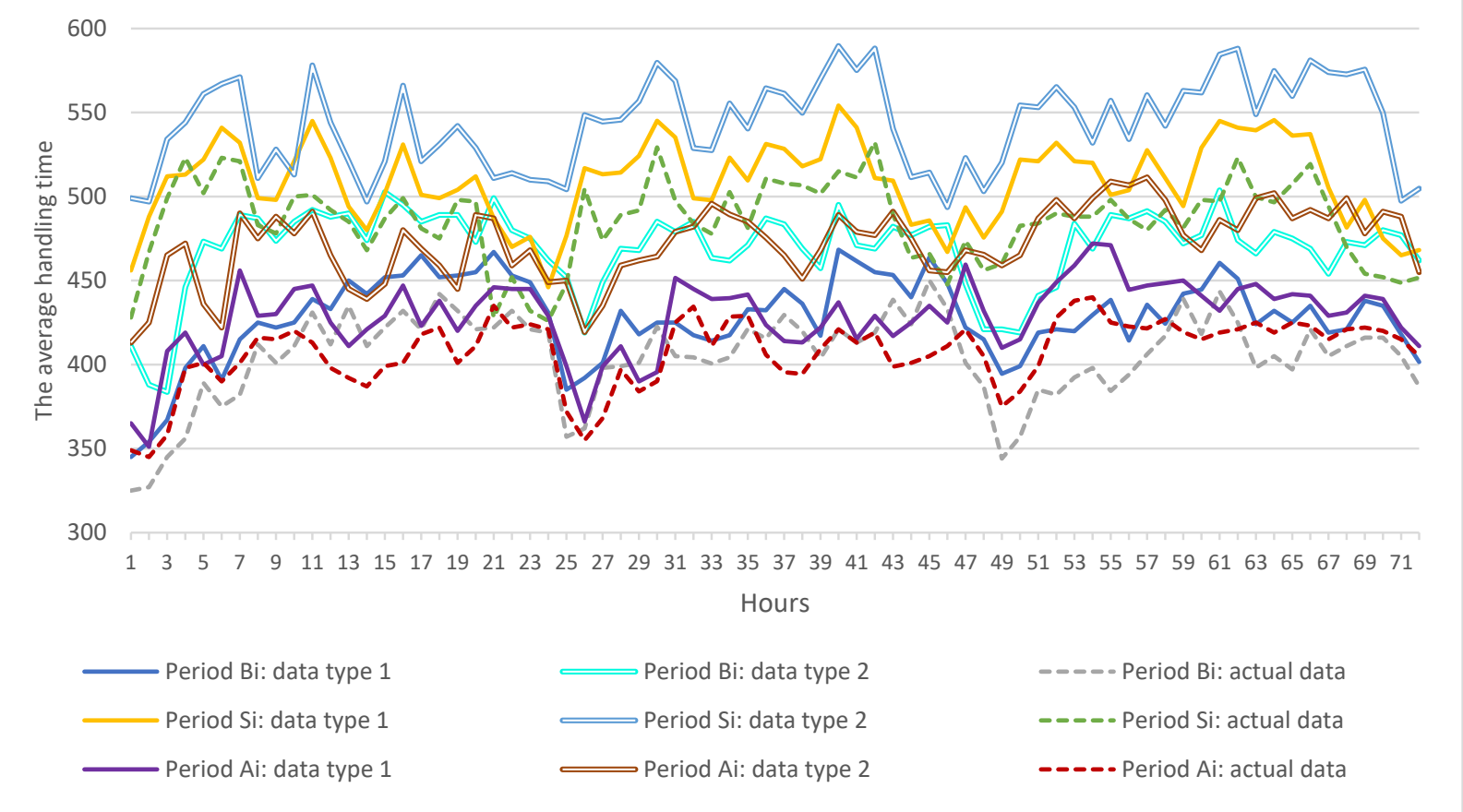

Figure 7. The average handling time on two data types with actual data.

In the final step, the number of agents was classified in two categories: (1) service level classification for data type 1; and (2) the existing service level for data type 2 . For the service level classification, we selected the number of calls from the best forecasting. Table 8 shows the incoming call forecasting classified into three categories. The results are shown in the same class for the same periods: Category 1 for internet and promotion, Category 2 for general information, and Category 3 for billing. Then, the service was adjusted under the $90 / 10$ rule, $80 / 20$ rule, and 70/10 rule for Category 1, Category 2, and Category 3, respectively. For data type 2 , the existing service level was adjusted under the 80/20 rule. 
Table 8. The classifications for data type 1 .

\begin{tabular}{|c|c|c|c|c|c|c|c|c|c|}
\hline \multirow{2}{*}{ Data Type } & \multicolumn{3}{|c|}{ Period $B_{i}$} & \multicolumn{3}{|c|}{ Period $S_{i}$} & \multicolumn{3}{|c|}{$\operatorname{Period} A_{i}$} \\
\hline & $\begin{array}{l}\text { The } \\
\text { Number } \\
\text { of Calls }\end{array}$ & Percent & Category & $\begin{array}{l}\text { The } \\
\text { Number } \\
\text { of Calls }\end{array}$ & Percent & Category & $\begin{array}{l}\text { The } \\
\text { Number } \\
\text { of Calls }\end{array}$ & Percent & Category \\
\hline 1. Billing & 2578 & $3.88 \%$ & 3. & 3458 & $4.26 \%$ & 3. & 3015 & $4.55 \%$ & 3. \\
\hline 2. Internet & 27,125 & $40.78 \%$ & 1. & 31,352 & $38.66 \%$ & 1. & 27,025 & $40.79 \%$ & 1. \\
\hline 3. Promotion & 27,058 & $40.68 \%$ & 1. & 34,126 & $42.08 \%$ & 1. & 26,589 & $40.13 \%$ & 1. \\
\hline $\begin{array}{l}\text { 4. General } \\
\text { information }\end{array}$ & 9752 & $14.66 \%$ & 2. & 12,153 & $14.99 \%$ & 2. & 9632 & $14.54 \%$ & 2. \\
\hline
\end{tabular}

\subsection{Model Simulation Results}

The results of the simulation and their significance are discussed through five steps.

\subsubsection{Step 1: Goal Setting Simulation}

Simulation can be used to predict the number of agents and to compare the number of customers waiting in the call center under Model (1) and Model (2).

\subsubsection{Step 2: Data Identification}

The actual data in 2019 and two models discussed in the simulation model were tested based on the simulation goal. There were three periods $\left(B_{i}, S_{i}, A_{i}\right)$.

\subsubsection{Step 3: Configuration of the Data}

In this step, the results for each part are discussed below.

Part 1: Simulation: Actual data.

The number of agents was determined by using the actual data for simulation in each period. Therefore, altogether, three time series datasets were analyzed. Figure 8 presents a simulation application for the number of agents from actual data. Following the procedure for simulation data type 1 , the actual incoming call data were classified into three categories: Category 1 for internet and promotion, Category 2 for general information, and Category 3 for billing. The results showed incoming calls of the same class in the same periods. The output results for the number of agents from three periods under data type 1 and data type 2 are shown in Figure 9.

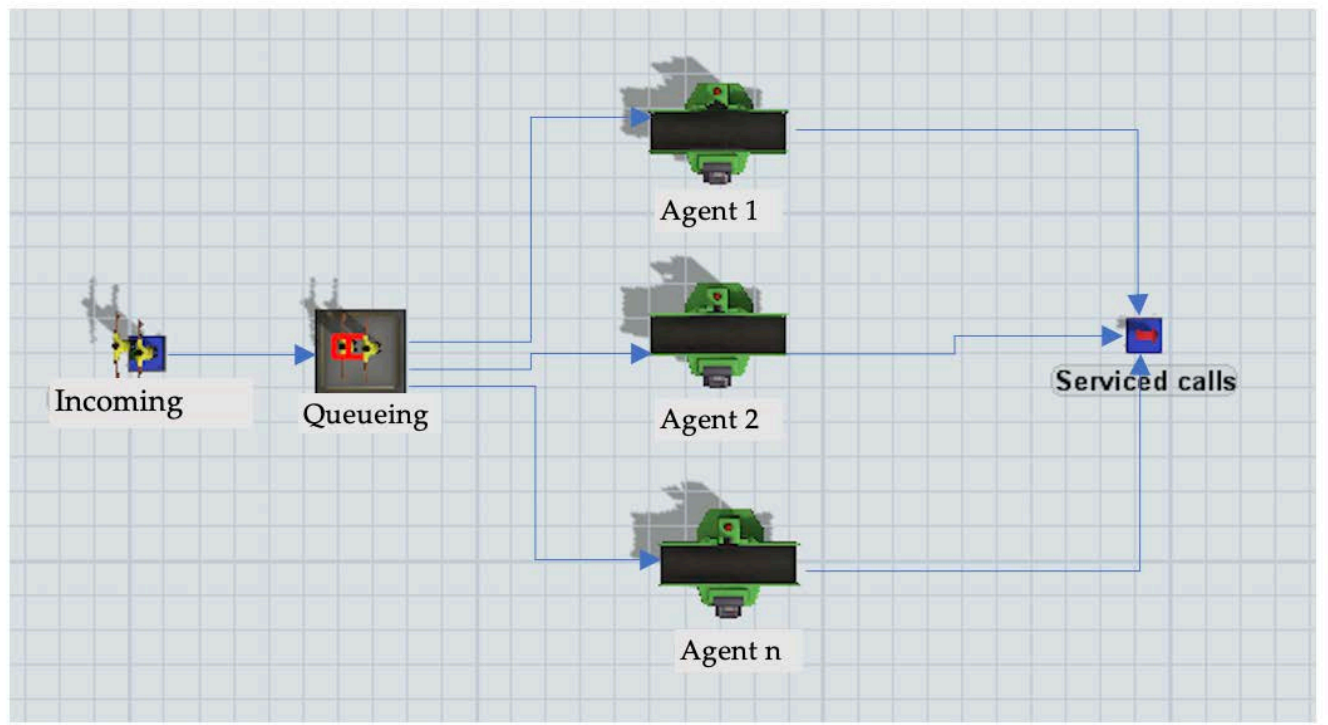

Figure 8. Simulation layout for the number of agents. 


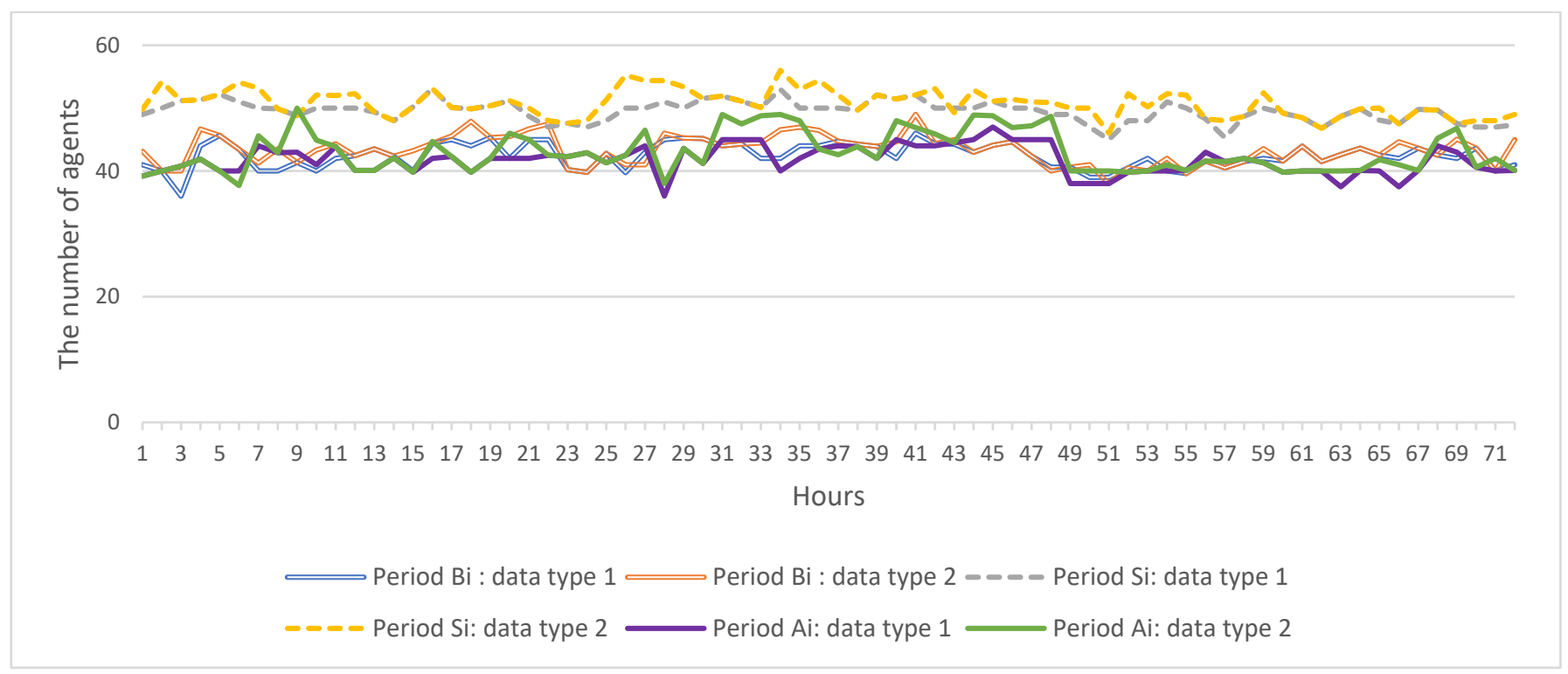

Figure 9. The number of agents from actual data of type 1 and type 2.

Part 2: Simulation: Model (1) and Model (2).

The previous steps consisted of using the incoming calls, average handling time and the number of agents as the input parameters in the simulation to determine the number of customers waiting in the call center. Both models were simulated, and the number of customers waiting in the call center is shown in Table 9.

Table 9. The number of customers waiting in the three periods.

\begin{tabular}{ccccc}
\hline Period & Model & First Day & Second Day & Last Day \\
\hline \multirow{2}{*}{$B_{i}$} & Model (1) & 323 & 366 & 239 \\
$S_{i}$ & Model (2) & 684 & 676 & 491 \\
& Model (1) & 612 & 394 & 251 \\
$A_{i}$ & Model (2) & 1134 & 756 & 894 \\
& Model (1) & 376 & 342 & 198 \\
& Model (2) & 484 & 489 & 285 \\
\hline
\end{tabular}

Part 3: Comparison of the two models.

In Table 9, the number of customers waiting in the call center is shown separately in three shifts for the two models. The number of customers waiting in the call center from Model (2) was higher than that from Model (1) for all shifts and all periods. Figure 10 compares the number of customers waiting in the call center under the two models for each hour over three days. For the first day, we can see a higher number of customers waiting during the Songkran festival period for Model (2) than for the other periods. This number was high at 10.00 a.m.-10.59 a.m. in the first shift. For the second day, a high number of customers waiting for the second day occurred in the first shift at 10.00 a.m.-10.59 a.m. during the Songkran festival period for Model (2). Additionally, the number of customers waiting on the last day during the Songkran festival period for Model (2) was high at 12.00 a.m. -12.59 a.m. in the first shift. 


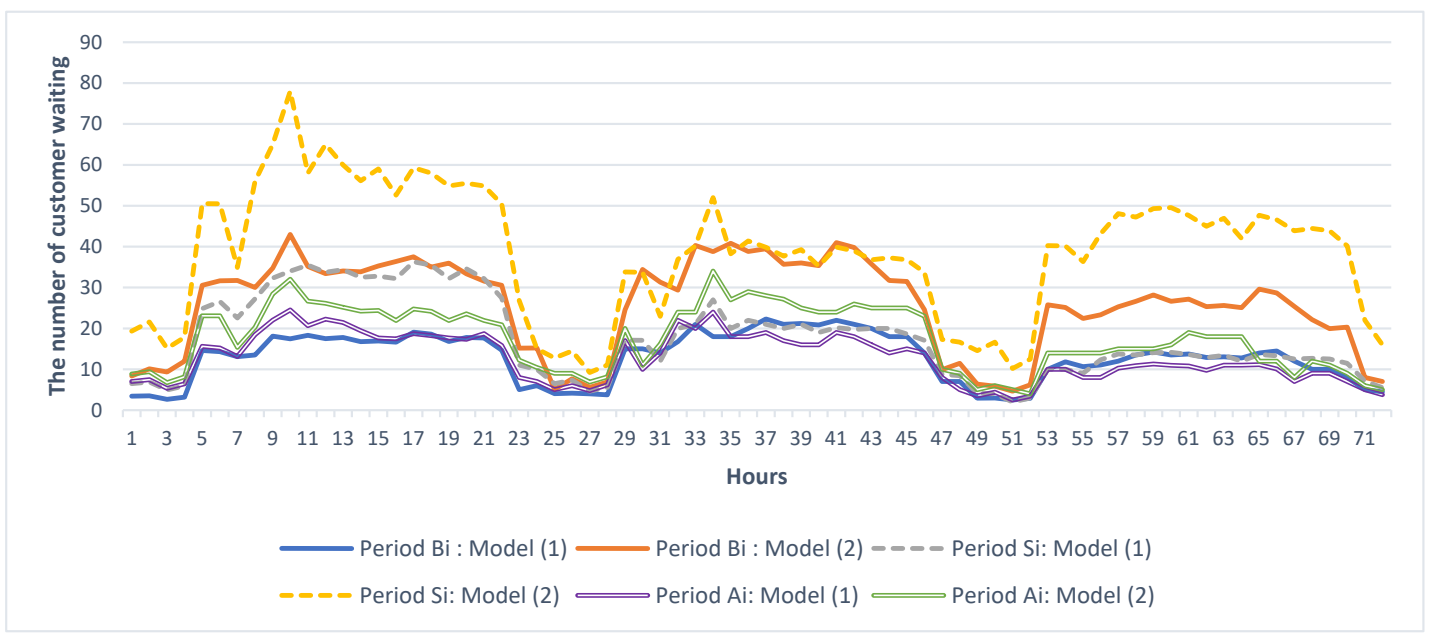

Figure 10. The number of customers waiting by periods.

\subsubsection{Step 4: Verification and Validation}

The simulation was carried out for three periods. The simulation time for each period was $259,200 \mathrm{~s}$ ( 3 days $\times 24 \mathrm{~h} \times 60 \mathrm{~min} \times 60 \mathrm{~s}$ ). After each period ran, the corresponding data were generated for testing whether the model was appropriate for simulation or not. The percentage errors of the simulations were $3.26 \%$ and $3.45 \%$ for data type 1 and data type 2 , respectively. The statistical test of the model proved that the percentage errors of the simulations of data type 1 and data type 2 were not significantly different.

\subsubsection{Step 5: Formulation of the Model}

For this step, we can conclude that the number of customers waiting in the call center for Model (2) was higher than that for Model (1), for all periods.

\subsection{Model Evaluation Results}

We next describe a cost comparison of wages and energy charges. The results of the two evaluations are as follows:

\subsubsection{Wages}

The wages from the two models are displayed in Table 10. From Table 10, the wages of Model (2) were higher than those of Model (1). The percentage differences between the costs under Model (1) and Model (2) were 34.56\%, 15.03\%, and 16.25\% for the same days a week before the Songkran festival period, during the Songkran festival, and a week after the Songkran festival period, respectively.

Table 10. Wage costs of the three periods for the two models.

\begin{tabular}{|c|c|c|c|c|c|c|}
\hline \multirow{2}{*}{ Period } & \multirow{2}{*}{ Model } & \multicolumn{3}{|c|}{ Wage Costs (THB) } & \multirow{2}{*}{$\begin{array}{c}\text { Total Wage Costs } \\
\text { (THB) }\end{array}$} & \multirow{2}{*}{$\begin{array}{c}\text { Cost Difference } \\
\text { (Percentage) }\end{array}$} \\
\hline & & First Day & Second Day & Last Day & & \\
\hline \multirow{2}{*}{$B_{i}$} & Model (1) & 44,685 & 46,671 & 43,692 & 135,048 & \multirow[b]{2}{*}{34.56} \\
\hline & Model (2) & 59,580 & 63,552 & 58,587 & 181,719 & \\
\hline \multirow{2}{*}{$S_{i}$} & Model (1) & 54,615 & 59,580 & 57,594 & 171,789 & \multirow[b]{2}{*}{15.03} \\
\hline & Model (2) & 64,545 & 69,510 & 63,552 & 197,607 & \\
\hline \multirow{2}{*}{$A_{i}$} & Model (1) & 51,636 & 54,615 & 52,629 & 158,880 & \multirow[b]{2}{*}{16.25} \\
\hline & Model (2) & 59,580 & 64,545 & 60,573 & 184,698 & \\
\hline
\end{tabular}

\subsubsection{Energy Costs}

The energy cost was calculated considering a desktop computer model $2.3 \mathrm{GHz}$ processor 3 GB RAM working for $24 \mathrm{~h}$. The results for this cost for the three periods are 
presented in Table 11. The differences between the costs under Model (1) and Model (2) were THB 7586.50, THB 7252.17, and THB 8207.28 for the same days a week before the Songkran festival period, during the Songkran festival, and a week after the Songkran festival period. Thus, Model (2) provided a higher energy cost than Model (1).

Table 11. Energy costs of the three periods for the two models.

\begin{tabular}{cccccc}
\hline \multirow{2}{*}{ Period } & \multirow{2}{*}{ Model } & \multicolumn{3}{c}{ Energy Costs (THB) } & \multirow{2}{*}{ Total Energy Cost (THB) } \\
\cline { 3 - 5 } & & First Day & Second Day & Last Day & 8955.18 \\
& Model (1) & 3021.12 & 3075.65 & 2858.41 & $16,541.68$ \\
$B_{i}$ & Model (2) & 5583.97 & 5936.22 & 5021.49 & $10,508.54$ \\
& Model (1) & 3505.53 & 3607.12 & 3395.89 & $17,760.71$ \\
$S_{i}$ & Model (2) & 5809.81 & 6114.23 & 5836.67 & 8822.78 \\
& Model (1) & 2909.66 & 3170.82 & 2742.30 & $17,030.06$ \\
\hline
\end{tabular}

\section{Validation of the Proposed Workforce Planning Framework}

To ensure that the proposed workforce planning framework was appropriate for the call center during the other special events, the workforce planning during a new mobile phone event was tested.

The proposed process was tested for the release a new mobile phone promotion package from September to December each year. The nonevent period consisted of the other months in one year. We applied the proposed framework in four steps, as follows.

Step 1 First, there were three separate periods: (1) four months before the release of a new mobile phone promotion package; (2) during release of a new mobile phone promotion package; and (3) four months after the release of a new mobile phone promotion package, as shown in Equations (30)-(32), respectively. The months during 2017-2019 in each period are presented in Table 12.

$$
\begin{aligned}
B M_{i} & =\left\{B M_{1}, \ldots, B M_{t m-1}, B M t_{m}\right\} \\
S M_{i} & =\left\{S M_{1}, \ldots, S M_{t m-1}, S M_{t m}\right\} \\
A M_{i} & =\left\{A M_{1}, \ldots, A V_{t m-1}, A V t_{m}\right\}
\end{aligned}
$$

where:

$B M_{i}$ is a set of time series values for four months before the event period;

$S M_{i}$ is a set of time series values during the event period;

$A M_{i}$ is a set of time series values four months after the event period;

$t m$ is time.

Table 12. The months for each period.

\begin{tabular}{cccccc}
\hline Period & Day & Month & 1st Year & 2nd Year & 3rd Year \\
\hline$B M_{i}$ & $B M_{i_{1}}$ & May & & & \\
& $B M_{i_{2}}$ & June & 2017 & 2018 & 2019 \\
& $B M_{i_{3}}$ & July & & & \\
& $B M_{i_{4}}$ & August & & & \\
$S M_{i}$ & $S M_{i_{1}}$ & September & & 2019 \\
& $S M_{i_{2}}$ & October & 27 & & \\
& $S M_{i_{3}}$ & November & & & \\
$A M_{i}$ & $S M_{i_{4}}$ & December & & 2018 \\
& $A M_{i_{1}}$ & January & & & \\
& $A M_{i_{2}}$ & February & 2018 & & \\
& $A M_{i_{3}}$ & March & & & \\
& $A M_{i_{4}}$ & April & & & \\
\hline
\end{tabular}


Step 2 Then, the different data types were separated into two models. This step followed the details of the two models from Table 2. The data collection was the same as that during the Songkran festival event. Then, the time series forecasting from data type 1 was applied to forecast three periods, and the results of the MAPE are displayed in Table 13. The parameter values in the parentheses were the values that provided the minimum forecasting error. The incoming calls and average handling time forecasting for data type 2 are shown in Table 14. For the number of agents required, we selected the number of calls from the best forecasting for data type 1 . The results are shown in the same class for the same periods, Category 1 for general information and promotions, Category 2 for internet, and Category 3 for billing. Then, the service level was adjusted under the 90/10 rule, 80/20 rule, and 70/10 rule for Category 1, Category 2, and Category 3 , respectively. The existing service level for data type 2 was adjusted under the 80/20 rule.

Table 13. Comparison of the MAPEs for data type 1 during a new mobile phone event.

\begin{tabular}{|c|c|c|c|c|c|}
\hline Forecasting Type & Data Type & Period & $\begin{array}{l}\text { Holt's Two Parameter } \\
\qquad(\alpha, \beta)\end{array}$ & $\begin{array}{l}\text { Holt-Winters } \\
\qquad(\alpha, \beta, \gamma)\end{array}$ & $\begin{array}{c}\text { SARIMA } \\
(\mathrm{p}, \mathrm{d}, \mathrm{q}) \times(\mathrm{P}, \mathrm{D}, \mathrm{Q}) \mathrm{m}\end{array}$ \\
\hline \multirow{12}{*}{ 1. Incoming calls } & \multirow{3}{*}{ 1.1. Billing } & $B M_{i}$ & $10.53(0.5,0.1)$ & $11.21(0.1,0.3,0.1)$ & $10.35(1,0,1)(0,1,1)[24]$ \\
\hline & & $S M_{i}$ & $11.19(0.1,0.5)$ & $9.22(0.1,0.1,0.5)$ & $9.78(1,0,1)(1,1,1)[24]$ \\
\hline & & $A M_{i}$ & $13.85(0.9,0.1)$ & $9.15(0.1,0.2,0.1)$ & $9.56(1,0,1)(0,1,1)[24]$ \\
\hline & \multirow{3}{*}{ 1.2. Internet } & $B M_{i}$ & $12.25(0.1,0.5)$ & $10.53(0.1,0.5,0.5)$ & $10.11(1,0,1)(1,1,1)[24]$ \\
\hline & & $S M_{i}$ & $15.45(0.5,0.2)$ & $12.18(0.5,0.3,0.1)$ & $10.45(1,0,1)(1,1,1)[24]$ \\
\hline & & $A M_{i}$ & $12.75(0.1,0.6)$ & $11.12(0.1,0.9,0.5)$ & $9.84(1,0,1)(0,1,1)[24]$ \\
\hline & \multirow{3}{*}{ 1.3. Promotion } & $B M_{i}$ & $14.13(0.4,0.1)$ & $10.71(0.5,0.2,0.1)$ & $10.95(1,0,1)(0,1,1)[24]$ \\
\hline & & $S M_{i}$ & $15.65(0.9,0.5)$ & $11.92(0.1,0.5,0.1)$ & $11.15(\mathbf{1}, \mathbf{0}, \mathbf{1})(\mathbf{0}, \mathbf{1}, \mathbf{1})[24]$ \\
\hline & & $A M_{i}$. & $18.41(0.1,0.5)$ & $12.27(0.9,0.5,0.1)$ & $13.24(1,0,1)(1,1,1)[24]$ \\
\hline & \multirow{3}{*}{$\begin{array}{l}\text { 1.4. General } \\
\text { information }\end{array}$} & $B M_{i}$ & $15.89(0.5,0.1)$ & $9.27(0.5,0.3,0.5)$ & $11.78(1,0,1)(0,1,1)[24]$ \\
\hline & & $S M_{i}$ & $15.71(0.5,0.9)$ & $8.12(0.6,0.9,0.1)$ & $9.37(1,0,1)(1,1,1)[24]$ \\
\hline & & $A M_{i}$ & $15.59(0.5,0.6)$ & $9.19(0.5,0.5,0.1)$ & $9.04(1,0,1)(1,1,1)[24]$ \\
\hline \multirow{12}{*}{$\begin{array}{l}\text { 2. Average } \\
\text { handling time }\end{array}$} & \multirow{3}{*}{ 2.1. Billing } & $B M_{i}$ & $9.43(0.1,0.1)$ & $8.15(0.1,0.9,0.5)$ & $8.38(1,0,2)(0,1,1)[24]$ \\
\hline & & $S M_{i}$ & $9.12(0.1,0.9)$ & $7.32(0.1,0.5,0.1)$ & $8.75(1,0,1)(1,1,1)[24]$ \\
\hline & & $A M_{i}$ & $10.15(0.1,0.5)$ & $8.51(0.1,0.5,0.1)$ & $8.97(1,0,1)(0,1,1)[24]$ \\
\hline & \multirow[t]{2}{*}{ 2.2. Internet } & $B M_{i}$ & $9.45(0.5,0.1)$ & $8.73(0.1,0.9,0.1)$ & $9.13(1,0,1)(1,1,1)[24]$ \\
\hline & & $S M_{i}$ & $10.55(0.1,0.1)$ & $8.15(0.1,0.5,0.5)$ & $9.22(1,0,1)(0,1,1)[24]$ \\
\hline & \multirow{4}{*}{ 2.3. Promotion } & $A M_{i}$ & $10.42(0.1,0.5)$ & $8.79(0.5,0.9,0.5)$ & $9.73(1,0,1)(0,1,1)[24]$ \\
\hline & & $B M_{i}$ & $9.43(0.1,0.4)$ & $8.22(0.1,0.5,0.1)$ & $8.75(1,0,1)(0,1,1)[24]$ \\
\hline & & $S M_{i}$ & $9.13(0.1,0.5)$ & $8.79(0.9,0.4,0.1)$ & $8.98(1,0,1)(1,1,1)[24]$ \\
\hline & & $A M_{i}$ & $8.42(0.5,0.1)$ & $7.86(0.1,0.0 .1)$ & $8.12(1,0,2)(1,1,1)[24]$ \\
\hline & \multirow{3}{*}{$\begin{array}{l}\text { 2.4. General } \\
\text { information }\end{array}$} & $B M_{i}$ & $9.46(0.5,0.1)$ & $8.81(0.5,0.1,0.5)$ & $8.85(1,0,2)(0,1,1)[24]$ \\
\hline & & $S M_{i}$ & $9.12(0.5,0.1)$ & $7.84(0.5,0.1,0.9)$ & $8.45(1,0,1)(1,1,1)[24]$ \\
\hline & & $A M_{i}$ & $9.37(0.1,0.7)$ & $7.59(0.1,0.1,0.1)$ & $9.12(1,0,1)(1,1,1)[24]$ \\
\hline
\end{tabular}

Remark: bold values indicate the lowest forecasting error.

Table 14. The MAPEs for data type 2 during a new mobile phone event.

\begin{tabular}{ccc}
\hline Forecasting Type & Period & Multiplicative Decomposition \\
\hline & $B M_{i}$ & 21.47 \\
1. Incoming calls & $S M_{i}$ & 35.39 \\
& $A M_{i}$ & 31.41 \\
& $B M_{i}$ & 20.17 \\
2. Average handling time & $S M_{i}$ & 22.91 \\
& $A M_{i}$ & 19.25 \\
\hline
\end{tabular}

Step 3 For the simulation model, the simulation methodology from Figure 4 was followed. The comparison of the number of customers waiting in the call center is shown in Table 15. The number of customers waiting in the call center of Model (1) was lower than that of Model (2). 
Table 15. Comparison of the number of customers waiting for the three periods with Model (1) and Model (2).

\begin{tabular}{cccc}
\hline \multirow{2}{*}{ Model } & \multicolumn{3}{c}{ Periods } \\
\cline { 2 - 4 } & $\boldsymbol{B M}_{\boldsymbol{i}}$ & $\boldsymbol{S \boldsymbol { M } _ { \boldsymbol { i } }}$ & $\boldsymbol{A M}_{\boldsymbol{i}}$ \\
\hline Model (1) & 3100 & 3500 & 2070 \\
Model (2) & 9840 & 11,280 & 8640 \\
\hline
\end{tabular}

Step 4 Finally, the model that had the lowest wage costs and electricity costs was selected. Table 16 shows a comparison of the costs for these two models, and those of Model (1) were lower than those of Model (2). It can be concluded that the proposed framework can be applied to workforce planning in other event periods.

Table 16. Comparison of costs for Model (1) and Model (2).

\begin{tabular}{cccc}
\hline Cost (THB) & Period & Model (1) & Model (2) \\
\hline \multirow{3}{*}{ Wages } & $B M_{i}$ & $5,362,200$ & $7,149,600$ \\
& $S M_{i}$ & $6,196,320$ & $7,983,720$ \\
& $A M_{i}$ & $5,958,000$ & $6,434,640$ \\
\multirow{3}{*}{ Electricity } & $B M_{i}$ & $70,551.00$ & $94,078.80$ \\
& $S M_{i}$ & $81,525.60$ & $105,054.66$ \\
& $A M_{i}$ & $78,390.00$ & $84,670.92$ \\
\hline
\end{tabular}

However, this proposed workforce planning framework is not only for an event in Thailand. Workforce planners can use this framework to support workforce planning during other special event periods, such as Christmas, the New Year festival, Chinese New Year, and during the promotion period. The framework will help to select the appropriate model during those events.

\section{Conclusions}

A workforce planning framework in a call center during the Songkran festival event was presented in this article. The purpose of this framework was to evaluate the total cost. It included four main steps.

(1) The first step was data analysis through a three-period study. The weekday results for each period in April were shown;

(2) Next, two models were defined. The proposed method was Model (1), and the existing method was Model (2). There were two separate data types (data type 1 and data type 2) with three steps. For the data collection, data type 1 separated four types of customer questions (billing, internet, promotion, and general information), and data type 2 combined all types of customer questions. Then, the time series forecasting for data type 1 was compared with Holt's two-parameter forecasting method, the Holt-Winters forecasting method, and the SARIMA forecasting method. Data type 2 was the existing forecasting method (multiplicative decomposition). Data type 1 had less forecasting errors than data type 2 . Then, the number of agents required and data type 1 were classified into three categories. The results were shown in the same class in the same periods. The service was adjusted under the $90 / 10$ rule, $80 / 20$ rule, and $70 / 10$ rule for Category 1, Category 2, and Category 3, respectively. For data type 2, the existing service level was adjusted under the $80 / 20$ rule;

(3) Third, the simulation of the number of customers waiting in the call centers showed that Model (2) yielded a higher result than Model (1);

(4) For the last step, the energy cost for wages and energy charges were calculated, and it was found that they were also higher for Model (2) than those for Model (1).

This proposed framework presents alternative models for analysis and formulates a simulation model for cost comparison. There are three important technical takeaways from 
the proposed workforce planning framework: (1) the number of incoming calls during events is higher than that in other periods; (2) questions from customers commonly regard the internet and promotions; and (3) an accurate forecasting method and classification service level reduce the cost and number of customers waiting at the call center. The main contributions of this paper are the new concept of the workforce planning framework for selecting the best forecasting model, and optimizing workforce planning that provides minimum wage and computer electricity costs for mobile call centers during the Songkran festival event.

Workforce planners can use this framework to support workforce planning and customer satisfaction during other event periods, such as during the release of a new mobile phone promotion package. This result shows that the proposed framework is better than the existing framework. It can help companies, professionals and researchers to decide on an energy saving program to reduce their operating costs, and consequently assist in development in this area. However, the limitation of this paper is the period of collecting the incoming calls data. We excluded the data from 2019-2021 because various activities for the Songkran festival were forbidden due to COVID-19. Therefore, the proposed model is not provable for this period of time.

In future research, software for selecting models will be included in this framework, such as including an algorithm to detect the best model and best forecasting method. Therefore, future research should address separate customer questions that could guide agenttraining courses. There is also a need to develop a greater capacity for customer satisfaction.

Author Contributions: Conceptualization, T.C. and A.U.; data curation, T.C.; formal analysis, T.C. and A.U.; methodology, T.C. and A.U.; resources, T.C.; software, T.C.; supervision, A.U.; validation, A.U.; writing-original draft, T.C.; writing-review and editing, T.C. and A.U. All authors have read and agreed to the published version of the manuscript.

Funding: This research was funded by the Petchra Pra Jom Klao Ph.D. Research Scholarship (number 12/2557) and the Department of Production Engineering at King Mongkut's University of Technology, Thonburi, Thailand.

Institutional Review Board Statement: Not applicable.

Informed Consent Statement: Not applicable.

Data Availability Statement: Not applicable.

Acknowledgments: The authors would like to thank you the Thai mobile communication call center company for providing data and insight. Also, we would like to thank you to the anonymous reviewers for their insightful comments and suggestions.

Conflicts of Interest: The authors declare no conflict of interest.

\section{References}

1. Songkran 2017 Spurred over 45 Billion Baht in Spending in Thailand. Available online: https://www.tatnews.org/2017/04/ songkran-2017-spurred-45-billion-baht-spending-thailand/ (accessed on 31 January 2022).

2. Steckley, S.G.; Henderson, S.G.; Mehrotra, V. Forecast errors in service systems. J. Probab. Eng. Inf. Sci. 2009, $23,305-332$. [CrossRef]

3. Akintayo, D.I.; Babajide, E.O. Trends in professional education and workers development in Nigeria. J. Educ. Res. Dev. 2005, 6, 21-30.

4. Liff, S. Manpower or HR Planning: What's in a Name? In Personnel Management, 3rd ed.; Bach, S., Sisson, K., Eds.; Oxford: Blackwell, OK, USA, 2000; pp. 93-110.

5. Mackay, M.; Lee, M. Choice of models for the analysis and forecasting of hospital beds. Health Care Manag. Sci. 2005, 8, 221-230. [CrossRef] [PubMed]

6. Jansen-Vullers, M.H.; Netjes, M.; Reijers, H.A.; Stegeman, M.J. A Redesign Framework for Call Centers. In Proceedings of the International Conference on Business Process Management; Springer: Berlin/Heidelberg, Germany, 2006; pp. 306-321.

7. Ye, H.; Brown, L.D.; Shen, H. Hazard rate estimation for call center customer patience time. IISE Trans. 2020, 52, 890-903. [CrossRef]

8. Singh, H.; Elam, M.E.; Cranor, B.D.; Moynihan, G.P.; Batson, R.G. Forecasting Applied to a Service Industry Call Centers. Technol. Interface J./Fall 2008, 9. Available online: https:/ /www.google.com.hk/url?sa=t\&rct=j\&q=\&esrc=s\&source=web\&cd=\&ved= 
2ahUKEwjAlfu9jYv2AhWSuaQKHTbABN4QFnoECAQQAQ\&url=http\%3A\%2F\%2Ftiij.org\%2Fissues $\% 2$ Fissues $\% 2$ Ffall2008\% 2FA_ELAM\%2FElam-Forecasting.pdf\&usg=AOvVaw3bMyBtOfFXRpsJ-OFlXrBj (accessed on 18 December 2020).

9. Taylor, J.W. Density Forecasting of Intraday Call Center Arrivals using Models Based on Exponential Smoothing. Manag. Sci. 2012, 58, 534-549. [CrossRef]

10. Hilas, C.S.; Goudos, S.K.; Sahalos, J.N. Seasonal decomposition and forecasting of telecommunication data: A comparative case study. Technol. Forecast. Soc. Chang. 2006, 73, 495-509. [CrossRef]

11. Shen, H.; Huang, J.Z. Interday Forecasting and Intraday Updating of Call Center Arrivals. Manuf. Serv. Oper. Manag. 2008, 10, 391-410. [CrossRef]

12. Xu, L.; Hu, X.; Wang, X.; Huang, G. Forecasting of Intraday Interval Arrivals for Small and Medium sized Call Centers with Emergencies. Procedia CIRP 2016, 56, 456-460. [CrossRef]

13. Jun, W.K.; Sung, H.H. Consecutive staffing solution using simulation in the contact center. Ind. Manag. Data Syst. 2010, 110, 718-730.

14. Mehrdad, A.; Vineet, K.; Yu, B.; Ron, W.; Babak, A. Optimization modeling of multi-skilled resources in prefabrication: Theorizing cost analysis of process integration in off-site construction. Autom. Constr. 2018, 95, 1-9.

15. Jeong, E.N.; Seongmoon, K. Workforce planning and deployment for a hospital reservation call center with abandonment cost and multiple tasks. Comput. Ind. Eng. 2013, 65, 297-309.

16. Andrew, G.; Chris, M.S. Using activity based costing and simulation to reduce cost at a Police communications centre. Policy Int. J. Police Strateg. Manag. 2017, 50, 1-23.

17. Rodrigo, W.T.S.; Fernando, W.D.T. An Enumerative Constraint Planning Framework for Airline Engineering Manpower Cost Optimization. In Proceedings of the 13th International Research Conference, General Sir John Kotelawala Defence University, Dehiwala-Mount Lavinia, Sri Lanka, 15-16 October 2020; pp. 20-26.

18. Marie, D.; Benoit, P.; Edouard, R.; Delphine, S.; Nathan, T. Toward an integrated workforce planning framework using structured equations. Eur. J. Oper. Res. 2017, 262, 217-230.

19. Michael, J.D.; Yingdong, L.; Mayank, S.; Mark, S.S.; Bo, Z. Stochastic Optimization Models for Workforce Planning, Operations, and Risk Management. Serv. Sci. 2018, 10, 40-57.

20. Julius, A.; Marina, A.E.; Shane, G.H. Optimizing Call Center Staffing Using Simulation and Analytic Center Cutting-Plane Methods. Manag. Sci. 2008, 54, 295-309.

21. Jose, P.G.; Julien, M.; Angel, R.; Julio, J.G. A Framework for Capacity and Operations Planning in Services Organizations Employing Workers with Intellectual Disabilities. Sustainability 2020, 12, 9713.

22. Aviso, K.B.; Mayol, A.P.; Promentilla, M.A.B.; Santos, J.R.; Tan, R.R.; Ubando, A.T.; Yu, K.D.S. Allocating human resources in organizations operating under crisis conditions: A fuzzy input-output optimization modeling framework. Resour. Conserv. Recycl. 2018, 128, 250-258. [CrossRef]

23. Nesrin, A.; Derya, I.; Muhittin, S. A Framework for New Workforce Skills in the Era of Industry 4.0. Int. J. Math. Eng. Manag. Sci. 2021, 6, 771-786.

24. Vijay, M.; Ozgur, O; Robert, S. Intelligent Procedures for Intra-Day Updating of Call Center Agent Schedules. Prod. Oper. Manag. 2010, 19, 353-367.

25. Sarfaraz, H.Z.; Morteza, Y.; Ali, E.T.; Arman, D. Application of a Gray-Based Decision Support Framework for Location Selection of a Temporary Hospital during COVID-19 Pandemic. Symmetry 2020, 12, 886.

26. Jordi, F.; Patxi, R.; Lluís, C.; Jordi, F. Balancing Workload and Workforce Capacity in Lean Management: Application to Multi-Model Assembly Lines. Appl. Sci. 2020, 10, 8829.

27. Jing, D.; Rouba, I. Managing Supply in the On-Demand Economy: Flexible Workers, Full-Time Employees, or Both? Oper. Res. 2020, 68, 1238-1264.

28. Kyong-Ah, K.; Timothy, G.F.; Lieny, J.; Adrien, M.; Natalie, E.; Ken, R.; Mia, K.; Alicia, L.S. Testing a holistic conceptual framework for early childhood teacher well-being. J. Sch. Psychol. 2021, 86, 178-197.

29. Graham, W.; Sion, C.; Martin, K. Strategic Workforce Planning in Healthcare: A multi-methodology approach. Eur. J. Operat. Res. 2018, 267, 250-263.

30. Chase, C.W. DEMAND-Driven Forecasting a Structured Approach to Forecasting, 2nd ed.; Wiley: Hoboken, NJ, USA, 2013; pp. 107-160.

31. Hyndman, R.J.; Athanasopoulos, G. Predicting: Principles and Practice; OTEXTS: Melbourne, Australia, 2014; pp. 145-253. ISBN 978-0-9875071-0-5.

32. Zolala, F.; Haghdoost, A.A.; Ahmadijouybari, T.; Salari, A.; Bahrampour, A.; Baneshi, M.R.; Razzaghi, A. Forecasting the Trend of Traffic Accident Mortality inWest Iran. Health Scope 2016, 5, e31336. [CrossRef]

33. Barba, L.; Rodríguez, N. A Novel Multilevel-SVD Method to Improve Multistep Ahead Forecasting in Traffic Accident Domain. Comput. Intell. Neurosci. 2017, 2017, 7951395. [CrossRef]

34. Wardono, A.A.; Siti, R. ARIMA method with the software Minitab and EVIEWS to forecast inflation in Semarang Indonasia. J. Theor. Appl. Inf. Technol. 2016, 94, 61-71.

35. Brezavscek, A.; Baggia, A. Optimization of a Call Centre Performance Using the Stochastic Queueing Models. Bus. Syst. Res. 2014, 5, 6-18. [CrossRef] 
36. Valeria, S.; Patrizia, R.; Massimo, C.; Carmelo, L. Simulation Goals and Metrics Identification. In Proceedings of the Federated Conference on Computer Science and Information Systems, Gdansk, Poland, 11-14 September 2016; pp. 1491-1494.

37. Bhakti, S.S.O.; Jame, H. Data identification and data collection methods in simulation: A case study at ORH Ltd. J. Simul. 2014, 8, 195-205.

38. Zhu, X.; Zhang, R.; Chu, F.; He, Z.; Li, J. A Flexsim-based Optimization for the Operation Process of Cold-Chain Logistics Distribution Centre. J. Appl. Res. Technol. 2014, 12, 270-278. [CrossRef]

39. Minimum Wage Rate. Available online: https://www.mol.go.th/wp-content/uploads/sites/2/2019/12/Prakadwage10--2 7December2019.pdf (accessed on 18 December 2020).

40. American Society of Heating Refrigerating and Air-Conditioning Engineers Inc. (ASHRAE). Fundamentals, SI Edition 18.12. 2009. Available online: http:/ / www.ashare.org (accessed on 14 March 2019).

41. Medium General Service 2015. Available online: https:/ / www.mea.or.th (accessed on 18 December 2020). 